EÜFBED - Fen Bilimleri Enstitüsü Dergisi Cilt-Sayı: 7-2 Y1l: 2014 149-158

\title{
SCREENING OF ANTIOXIDANT AND ANTIMICROBIAL POTENTIAL OF HAWTHORN (CREATAGUS MONOGYNA) FRUIT AND LEAVES EXTRACTS
}

\section{ALIÇ (CREATAGUS MONOGYNA) MEYVE VE YAPRAKLARINDA ANTİOKSIDANT VE ANTIMIIKROBİYAL POTANSIYYELININ İNCELENMESİ}

\author{
Nimet YİĞİT ${ }^{1}$, Demet YİĞİT2 ${ }^{*}$, Ali SÜLÜN² \\ ${ }^{1}$ Medical Laboratory Department, Ataturk Universty Health Services \\ Vocational Training School, 25070 Erzurum, Turkey \\ $2^{2 *}$ Department of Science Education Faculty, University of Erzincan, Erzincan, \\ 24030, Turkey \\ Geliş Tarihi: 06/05/2014 \\ Kabul Tarihi: 21/08/2014
}

\begin{abstract}
In the present study, water and methanol extracts of hawthorn (Creatagus monogyna) were studied for antioxidant and antimicrobial properties. The antioxidant properties of fruits and leaves were evaluated by determining 1,1-diphenyl-2-picrylhydrazyl (DPPH) radical scavenging activity. The water and methanol extracts of both fruits and leaves have antioxidant potential, ranging from $3.7 \%$ to $44 \%$. Antimicrobial activities of above extracts were also tested against clinical isolates of human pathogenic strains belonging to 4 bacteria, Enterobacter aerogenes, Escherichia coli, Pseudomonas aeruginosa, Staphylococcus aureus and 3 yeast species, Candida albicans, Candida glabrata and Candida parapsilosis, by disk-diffusion method. The minimal inhibition concentration (MIC) value of each active extracts was also determined. The most effective antibacterial activity was expressed by methanol extract of hawthorn leaves against Gram-positive bacteria $S$. aureus with $12 \mathrm{~mm}$ inhibition zone and $0.625 \mathrm{mg} / \mathrm{ml}$ MIC value. None of the extracts had antifungal activity against tested human pathogenic clinical isolates.
\end{abstract}

Keywords: Hawthorn (Creatagus monogyna), Antimicrobial activity, Antioxidant Activity

\section{ÖZET}

$\mathrm{Bu}$ çalışmada, alıcın (Creatagus monogyna) metanol ve su ektraktlarının antibakteriyal ve antioksidant aktiviteleri belirlenmiştir. Meyve ve yapraklardaki antioksidant aktivite 1,1-diphenyl-2-picrylhydrazyl (DPPH) radikal süpürme yöntemiyle belirlenmiş \%3.7 ile \%44 arasında değişen oranlarda aktivite tespit edilmiştir. Antimikrobiyal aktivite ise, hastalardan izole edilmiş olan 4 tür (Enterobacter aerogenes, Escherichia coli, Pseudomonas aeruginosa, Staphylococcus aureus) bakteri ve yine 3 tür (Candida 
Yiğit ve Diğerleri

albicans, Candida glabrata and Candida parapsilosis) maya üzerinde disk diffüzyon yöntemi kullanılarak belirlenmiştir. Disk diffüzyon yöntemiyle aktivite tespit edilen bakteriler için minimal inhibisyon konsantrasyonları (MIK) da belirlenmiştir. En yüksek aktivite, alıç yaprağının metanol ekstraktından, S. aureus türüne karşı $12 \mathrm{~mm}$ inhibisyon zonu ve $0.625 \mathrm{mg} / \mathrm{ml}$ MIKK değeriyle elde edilmiştir. Çalışmamızda antifungal aktivite tespit edilememiştir.

Anahtar Kelimeler: Alıç (Creatagus monogyna), Antimikrobiyal etki, Antioksidant etki

\section{INTRODUCTION}

During the past century, research on the role of fruits and vegetables in human nutrition has focused on essential nutrients. Essential nutrients are those that are required to prevent deficiency diseases. However the benefits of fruit and vegetable consumption cannot be entirely explained by the essential nutrient content of these foods (Beecher, 1999). Evidence is accumulating from recent research indicating that fruit and vegetables contain phytochemicals that possess health benefical bioactive properties. Supporting evidence is accruing from epidemiological studies, in vitro, in vivo, and in some cases, human clinical trials. The properties of phytochemicals groups of interest are chemically and mechanistically consistent with ways in which fruits and vegetables are believed to benefit health and reduce disease risk. Antioxidation is a major mechanisim by which fruit and vegetable phytochemicals are believed to contribute to health maintenance (Hodges and Kalt, 2003).

Crataegus monogyna is a small tree in the rose family often seen in hedgerows. It has been used as a medicinal herb by various cultures to treat similar disorders. Crataegus monogyna is used mainly to treat heart ailments such as angina and to improve circulation. It has a history of treating other afflictions as well, including indigestion and anxiety. The medicinal properties are contained in the flowers, leaves, and berries, with the berries containing the highest concentration of healing constituents (Baytop,1999).

Hawthorn is a recognized tonic for the heart and is beneficial in treating many cardiac disorders, including tachycardia, arrhythmia, congestive heart failure, and degenerative heart disease. Medical studies have proven the effectiveness of Crataegus monogyna 
Screening of Antioxidant and Antimicrobıal Potential of Hawthorn

in restoring a weakened cardiovascular system and regulating the heartbeat. The herb mildly stimulates the heart to pump slightly faster, which decreases the amount of stress placed on the heart (Long et al., 2006; Kumar et al., 2012).

Free 1,1-diphenyl-2-picrylhydrazyl (DPPH) radicals are mostly used in antioxidant tests for the determination of the activity of natural metabolites present in extracts because they can transmit the labile hydrogen atom to free radicals. This represents the simplest and the commonest mechanism of antioxidant protection. Bahrisahloul et al.( 2014) detected strongly influenced antioxidant efficacy of hawthorn with DPPH radical scavening method in their study. In some studies, extracts of leaves and fruits of Crataegus sp. exhibiting antioxidant activity (Kumar et al., 2012).

The chemistry and pharmacology of hawthorn is well documented (Kumar et al., 2012) Despite the extensive use of the different species of hawthorns, there are no studies on the antimicrobial activity of hawthorne especially on human clinical isolates. Therefore, attempts were made in this study to determine the antibacterial, antifungal and antioxidant activity of hawthorne fruit and leaves collected from Erzincan, Turkey.

\section{MATERIALS AND METHODS}

\subsection{Preparation of Extracts}

The hawthorn (Crataegus monogyna) fruits and leaves were collected in Erzincan, Turkey and identified (collected no:Kandemir 3946, Kandemir 3912) by Dr. Ali Kandemir, Biology Department of Science and Art Faculty, Erzincan University. Fruits samples were frozen at $-20 \circ \mathrm{C}$ until extraction. The leaves of hawthorn were dried in shade and powdered with a blender. The fruits and powdered leaves (20mg) were extracted with methanol in a Soxhlet apparatus for $24 \mathrm{~h}$. Then methanol was evaporated with rotary evaporator. Water extracts were also prepared by adding boiling water $(200 \mathrm{ml})$ to $20 \mathrm{~g}$ of powdered material in a glass flask and incubated at room temperature for 2 hours on a rotating shaker (200 rpm). Mixture was filtered using Whatman (No.1) filter paper and then filtrate was lyophilized. All extracts were stored in freezer at $-24^{\circ} \mathrm{C}$ until use (Yiğit et al., 2009).

EÜFBED - Fen Bilimleri Enstitüsü Dergisi Cilt-Sayı: 7-2 Yıl: 2014 149-158 
Yiğit ve Diğerleri

\subsection{DPPH radical scavenging activity}

Briefly, 0.5 mM DPPH (Fluka) radical solution in methanol was prepared, and then $1 \mathrm{ml}$ of this solution was mixed with $3 \mathrm{ml}$ of the sample solution. Final concentrations of extracts were 100 and 300 $\mu \mathrm{g} / \mathrm{ml}$. Butylated hydroxytoluene (BHT) was used as a positive control at the same concentrations. After incubation for $30 \mathrm{~min}$ in the dark, the absorbance was measured at $517 \mathrm{~nm}$. Decreasing the absorbance of the DPPH solution indicates an increase in DPPH radical scavenging activity. This activity is given as percent DPPH radical scavenging, which is calculated with the equation.

$$
\text { Activity } \%=\left[\frac{\text { ControlAbs. }- \text { SampleAbs. }}{\text { ControlAbs. }}\right] \times 100
$$

Control contains $1 \mathrm{ml}$ of DPPH solution mixed with $3 \mathrm{ml}$ of ethanol. The measurements of DPPH radical scavenging activity were carried out for two sample replications, and values are an average of two replicates.

\subsection{Antimicrobial Activity}

\subsubsection{Test Microorganisms}

Antimicrobial activity tests were carried out against clinical isolates of 33 bacterial strains and 23 Candida strains. Microorganisms were provided by Department of Clinical Microbiology, Medicine Faculty, Erzurum.

\subsubsection{Disk-diffusion assay}

The dried methanol and water extracts were dissolved in the extraction solvent (methanol and sterile distilled water). Final concentration was $30 \mathrm{mg} / \mathrm{ml}$.Antimicrobial test were than carried out by disk-diffusion method (Murray et al., 1995) using suspension containing $10^{8}$ colony forming unit $(\mathrm{CFU}) / \mathrm{ml}$ of bacteria, $10^{6} \mathrm{CFU} / \mathrm{ml}$ of yeast spread on nutrient agar (NA; Oxoid). The disk $(6 \mathrm{~mm}$ in diameter) were impregnated with extracts and placed on the inoculated NA. Negative controls were prepared using the same solvents employed to obtain extracts. Ofloxacin (Oxoid) for Grampositive bacteria, Cefaperazone-sulbactam (Oxoid) for Gramnegative bacteria and Amphotericin B (Sigma) for Candida spp. were used as positive controls. The inoculated plates were incubated at 
Screening of Antioxidant and Antimicrobıal Potential of Hawthorn

$37{ }^{\circ} \mathrm{C}$ for $24 \mathrm{~h}$ for clinical bacterial strains and at $35^{\circ} \mathrm{C}$ for $48 \mathrm{~h}$ for yeast. Then antimicrobial activity was evaluated by measuring the inhibition zone against test microorganisms.

\subsubsection{Minimal Inhibition Concentration (MIC)}

The minimal inhibition concentration (MIC) values were also determined for the microorganisms, which were found to sensitive for the methanol and/or water extracts of fruits in disk-diffusion assay. MIC values of extracts against microbial strains were determined based on a micro-well dilution method (Zgoda and Porter, 2001). The inoculations of microorganisms were prepared from $12 \mathrm{~h}$ broth cultures and suspensions were adjusted to 0.5 McFarland standard turbidity. Firstly, the extracts dissolved in 10\% dimethyl sulfoxide (DMSO) were diluted to $10 \mathrm{mg} / \mathrm{ml}$ and then serial two fold dilutions were made in a concentration range $(0.078-10$ $\mathrm{mg} / \mathrm{ml}$ ) in a sterile test tube containing nutrient broth (NB). The 96well plates were prepared by dispensing into each well $95 \mu \mathrm{NB}$ and $5 \mu \mathrm{l}$ of the inoculums. A $100 \mu \mathrm{l}$ of extracts initially prepared at the concentration of highest concentration was added the first well, then $100 \mu \mathrm{l}$ from serial dilutions was transferred into other consecutive wells. The plates covered with a sterile plate sealer and then incubated for $24 \mathrm{~h}$ (for bacterial strains) and $48 \mathrm{~h}$ (for fungal strains). The MIC was defined as the lowest concentration of the extracts to inhibit the growth of microorganisms.

\section{RESULT AND DISCUSSION}

Crataegus (hawthorn) species have been used traditionally since ancient times. Furthermore, it has been proposed that its antioxidant constituents account for its beneficial therapeutic effects.

The DPPH radical scavenging activities of all of the extracts were concentration dependent. DPPH radical scavenging activities of water and methanol extracts of hawthorn fruits and leaves were shown in Figure 1. The radical scavenging activity in both of methanol extracts of fruits and leaves was higher than water. As a concentration of $100 \mu \mathrm{g} / \mathrm{ml}$ water and methanol extract of hawthorn fruits, the scavenging activities were $3.7 \%$ and $7.5 \%$, while at a concentration of $300 \mu \mathrm{g} / \mathrm{ml}$ the respective activities were $13.4 \%$ and 
Yiğit ve Diğerleri

$22.4 \%$. There was a noticeable extract concentration effect in these extracts. Like fruit extracts, there was a detectable extract concentration activity in the leaves at the studied $(100-300 \mu \mathrm{g} / \mathrm{ml})$ concentration. Thus, at the concentration of $300 \mu \mathrm{g} / \mathrm{ml}$ water extract DPPH radical scavenging activity was $23.1 \%$ while it was $44 \%$ at 300 $\mu \mathrm{g} / \mathrm{ml}$ methanol extract of hawthorn leaves.

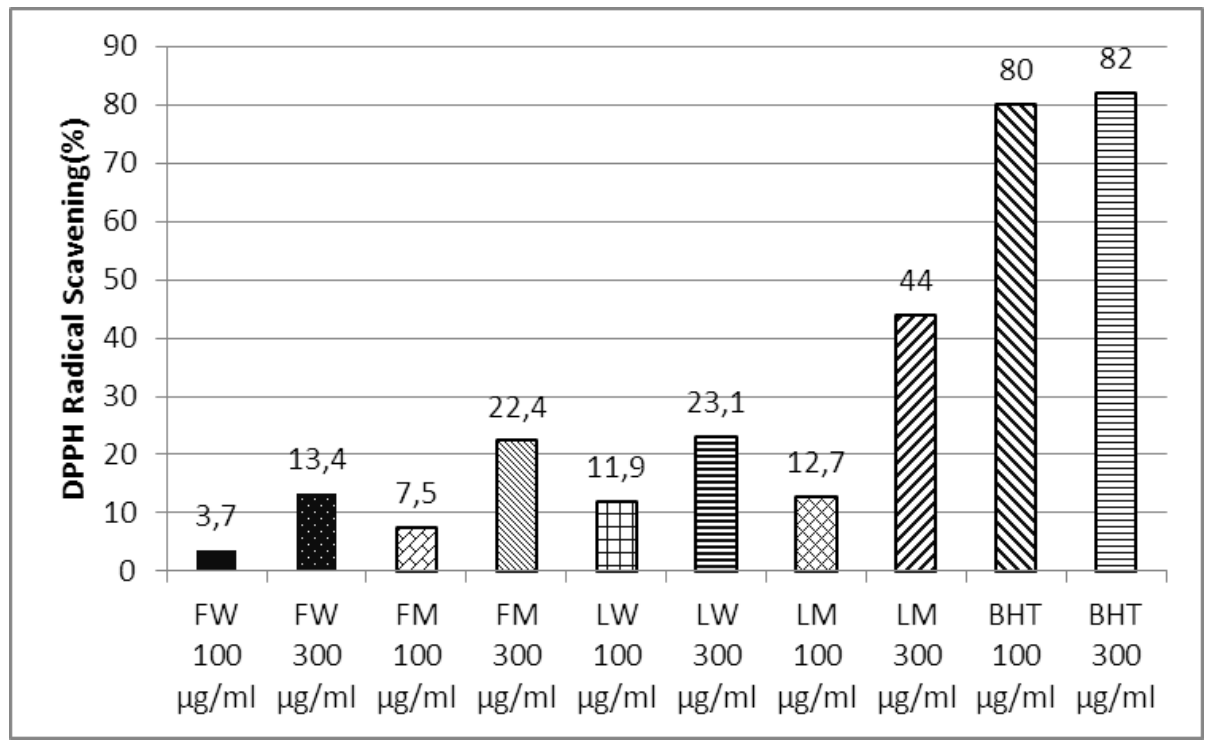

Figure 1. DPPH Radical Scavenging Activity (F: Hawthorn fruit, L:Hawthorn leaf, M: Methanol extract, W: Water extract, BHT: Butylated hydroxytoluene).

It has been reported that Crataegus oxyacantha L. fruit extracts exhibited strong scavenging activity against DPPH radicals, ranging from 60.6 to 89.9 \% (Kostic et al., 2012). These values are significantly higher than the DPPH radical scavenging activity found in our study. These differences can be explained by difference in the Crataegus species.

Disk diffusion assay is a standard method widely used for quick screening of natural products for antimicrobial activity. We have screened grape extracts using this method. Then, minimal inhibition concentration assays were used to determine the concentration at which the extracts are effective. In the present study, minimum inhibition concentration was determined for extracts which have $\geq 8 \mathrm{~mm}$ inhibition zone diameters by disk diffusion method. 
Screening of Antioxidant and Antimicrobıal Potential of Hawthorn

Table 1 and 2 shows the antimicrobial potentialities of Crataegus monogyna fruit and leaves extract against Staphylococcus aureus, Escherichia coli, Pseudomonas aeruginosa, Enterobacter aerogenes, Candida albicans, Candida glabrata and Candida parapisilosis- parapsilosis.

Table 1. Antimicrobial activity of methanol and water extracts of hawthorn fruits and leaves against some clinic isolates.

\begin{tabular}{lccccc}
\hline & \multicolumn{3}{c}{ Mean Inhibition Zone Diameter (mm) } \\
& Methanol Extracts & & Water Extracts \\
\cline { 2 - 4 } Microorganisim & Fruit & Leaf & Fruit & Leaf \\
\hline $\begin{array}{l}\text { Enterobacter } \\
\text { aerogenes }\end{array}$ & - & 10 & - & 10 \\
Escherichia coli & - & 10 & - & 8 \\
Staphylococcus aureus & 8 & 12 & - & 10 \\
$\begin{array}{l}\text { Pseudomonas } \\
\text { aeruginosa }\end{array}$ & - & - & - & - \\
& & & & & \\
Candida albicans & - & - & - & - \\
Candida glabrata & - & - & - & - \\
Candida parapsilosis & - & - & - & -
\end{tabular}

-: Not active, inhibition zone was no greater than $6 \mathrm{~mm}$; $(7-12 \mathrm{~mm})$, moderately active; (> 12), highly active. Negative controls (Methanol and Water) showed no inhibiting effect. Inhibition zone diameters of positive controls were ranging to $18-20 \mathrm{~mm}$ for Ofloxacin, 19-22 $\mathrm{mm}$ for Cefaperazone, and 12-15 mm for Amphotericin B, respectively.

The methanol and water negative control showed no inhibiting effect. The inhibition zone diameters and MIC values of positive controls were ranging to $18-20 \mathrm{~mm} ; 0.12-1 \mu \mathrm{g} / \mathrm{mL}$ for Ofloxacin, 19-22 mm; 0.5-1 $\mu \mathrm{g} / \mathrm{mL}$ for Cefaperazone and 12-15 mm and $0.5-1 \mu \mathrm{g} / \mathrm{mL}$ for Amphotericin B, respectively. 
Yiğit ve Diğerleri

There was only one fruit extracts showed antimicrobial activity against any tested microorganisms. As fruit extracts showed lowest antioxidant potential, this was very interesting. Methanol extract of it have shown antibacterial activity against only Staphylococcus aureus with $8 \mathrm{~mm}$ inhibition zone and $1.25 \mathrm{mg} / \mathrm{mL}$ MIC value amoung the tested microorganisms.

The highest antibacterial activity activity was found to be methanol leaves extract against Staphylococcus aureus with $12 \mathrm{~mm}$ inhibition zone and $0.625 \mathrm{mg} / \mathrm{mL}$ MIC.

Table 2. The MIC values $(\mathrm{mg} / \mathrm{ml})$ of methanol and water extracts of hawthorn fruits and leaves against bacteria tested in the micro dilution assay.

\begin{tabular}{lccccc}
\hline & \multicolumn{3}{c}{ Minimal Inhibition Concentration (MIC) mg/mL } \\
& \multicolumn{1}{l}{ Methanol Extracts } & & Water Extracts \\
\cline { 5 - 6 } Microorganisim & $\mathrm{F}$ & $\mathrm{L}$ & & $\mathrm{F}$ & $\mathrm{L}$ \\
\hline Escherichia coli & - & 1.25 & & - & 1.25 \\
Entrobacter aerogenes & - & 1.25 & & - & 1.25 \\
Staphylococcus aureus & 1.25 & 0.625 & & - & 1.25
\end{tabular}

MIC values of positive controls were ranging to $0.12-1 \mu \mathrm{g} / \mathrm{mL}$ for Ofloxacin, $0.12-0.5 \mu \mathrm{g} / \mathrm{mL}$ for Cefaperazone, respectively. (F: Fruit; L: Leaf).

The methanol extracts of leaves showed some antibacterial activity against Enterobacter aerogenes (10mm inhibition zone; $1.25 \mathrm{mg}$ $/ \mathrm{mL}$ MIC value) and E. coli (10 mm inhibition zone ; $1.25 \mathrm{mg} / \mathrm{mL}$ MIC value). But there is no activity on other bacteria and fungi ( Table 1). These results were supported by the other researchers in their studies (Bahri-sahloul et al., 2014). They reported that there is no antifungal activity screening from Creataegus sp. against four pathogenic fungi.

Our experiments revealed that hawthorn extracts, especially methanol leaves extracts, had a moderate antibacterial activity 
Screening of Antioxidant and Antimicrobıal Potential of Hawthorn

against some testing bacteria. In some studies, the hawthorn extracts showed higher antibacterial activity than did in our study (Kostic et al.,2012; Bahri-sahloul et al., 2014 ). There are differences between the results of mentioned studies. The observed differences are probably caused by the different methods and concentrations of tested extract solutions, but also, results depend on the susceptibility of tested wild strains, as well as the composition and amount of active components extracted from tested materials originated from different geographic areas, growth conditions of plant material as well as seasonal variations.

In conclusion, the results obtained show moderate antioxidant activity of methanol and water extracts of hawthorn fruits and leaves. The extract also show moderate antibacterial activity against the test bacterial strains. This study, emphasizes the potential of Crataegus monogyna in some cases, provide the basis for future researchs about this plant.

\section{REFERENCES}

Bahri-Sahloul R., Ben Fredj, R., Boughalleb N., Shriaa J., Saguem S., Hilbert J.,Francis T., Ammar,S., Bouzid, S. and Harzallah-Skhiri, F., 2014. Phenolic Composition and Antioxidant and AntimicrobialActivities of Extracts Obtained from Crataegus azarolus L. var.aronia (Willd.) Batt. Ovaries Calli. Hindawi Publishing Corporation Journal of Botany,111.

Baytop, T. (1999). Türkiyede bitkilerle tedavi. İstanbul Eczacıllk Fakültesi Yayınları, İstanbul, pp.269, 146-147.

Beecher, G.R., 1999. Phytonutrients role in metabolisim: Effects on resistance to degenerative processes. Nutrition Rev., 57, 3-6.

Hodges D:M:, Kalt, W., 2003. Health functionality of small fruits. Acta Hort., $626,17-23$.

Kostic, D. A, Velickovic, J. M, Mitic, S. S, Mitic, M.N.and Randelovic, S.S., 2012. Phenolic Content, and Antioxidant and Antimicrobial Activities of Crataegus Oxyacantha L (Rosaceae) Fruit Extract from Southeast Serbia. Tropical Journal of Pharmaceutical Research February. 11 (1): 117-124. 
Yiğit ve Diğerleri

Kumar, D., Arya V., Ali Bhat, Z., Khan, N., Prasad, D.N., 2012. The genus Crataegus: chemical and pharmacological perspectives. Brazilian Journal of Pharmacognosy 22(5): 1187-1200.

Long, S. R., . Carey, R. A, Crofoot, K. M., Proteau, P. J., and Filtz, T. M., 2006. Effect of hawthorn (Crataegus oxycantha) crude extract and chromatographic fractions on multiple activities in a culturedcardiomyocyte assay, Phytomedicine, vol. 13,no. 9-10, pp. 643-650.

Murray, P.R., Baron, E.J., Pfaller, M.A., Tenover, F.C and Yolke, R.H.,( 1995). Manual Clinical Microbiology. ASM, Washington, DC., pp.1356.

Yiğit,D., Yiğit, $\mathrm{N}$ and Mavi A.,(2009). Antioxidant and antimicrobialactivitiesof bitter and sweet apricot kernels. Brazilian Journal of Medical and biological research 42(4):346-352.

Zgoda, J.R. and Porter, J.R. (2001). A convenient microdilition method for screening natural products against bacteria and fungi. Pharmaceutical Biology, 39, 221-225. 